\title{
Level of Company Satisfaction to Result of Students Activities on Industrial Work Practices Period 2011-2015 School of Communication and Secretary (STIKS) Tarakanita in Solving The Problems of Archives Management
}

\author{
Bertha Reni Pudji Mawarti ${ }^{1}$, Astuti Widiati ${ }^{2}$, Robertus Koesmaryanto Oetomo ${ }^{3}$, Fredericka Krisma \\ Setyatami ${ }^{1}$, Petrus Dwi Ananto Pamungk as ${ }^{1 . *}$ \\ \{berthareni04@gmail.com ${ }^{1}$, astuti.widiati@yahoo.com ${ }^{2} \underline{\text { koemaryanto@yahoo.com }}^{3}$, \\ fredericka.krisma@g.mail.com ${ }^{1}$, petrusananto@ @mail.com ${ }^{1}$ \}
}

Secretary Programme, STIKS Tarakanita, Kompleks Billy \& Moon, Pondok Kelapa, Jakarta 13450, Indonesia, info@starki.id ${ }^{1}$

Secretary Programme, Asekma Don Bosco, Jl. Pulo Mas Barat V No. 50, Pulo Gadung, Jakarta 13210, Indonesia, info@asekmadb.ac.id ${ }^{2}$

Communication Departement, STIKS Tarakanita, Thamrin City Jakarta, Community Center Lt. 6, Thamrin Boulevard Street, Jakarta, Indonesia, info@

\begin{abstract}
Industrial work practices activities in STIKS Tarakanita has been going on since 2004 for the students of academic year 2001. Through the industrial work practices, students are expected to be able to compare and apply the academic knowledge that has been obtained and understand non-academic and non-technical concepts in the real world of work. This preliminary study is expected to provide information needed by the STIKS T arakanita industrial work practices unit in terms of decision-making for the implementation of industrial work practices in the following year. The research method used in this study using a descriptive quantitative where the type of data used in the study is the primary data obtained from the filling questionnaire with the respondents of the company that became industrial work practice of STIKS Tarakanita students period 2011-2015. From the results of data processing, it can be shown that the company was satisfied with industrial work practice activities conducted by students ST IKS T arakanita period 2011-2015. In addition, it is known that of 415 companies that become students' industrial work practice period 2011-2015 only 127 companies or about $30.6 \%$ of companies that become industrial work practice of ST IKS T arakanita students related to archive management issue and the rest are related to issues of layout, communication, SOP (Standard Company Operations), data processing, and computer usage at work.
\end{abstract}

Keywords: industrial work practice activities, archive management, archive management classification.

\section{Introduction}

In the student's industrial work practice guidebook of Diploma Three (D-3) Program, STIKS Secretary Study ProgramTarakanita [1] explained that in order to prepare students ready to work, apart from getting briefing in the form of concepts or theories given in college, it is neces sary to practice or practice directly in the industry, called Industrial Work Practice (Praktik Kerja Industri or abbreviated Prakerin). Prakerin is a practical activity for students of Diploma Three (D-3) Program of STIKS Secretariat Study Program of Tarakanita in business organization or state-owned enterprise which is carried out for three months. Prakerin at STIKS Tarakanita is held every year in the sixth semester exactly in April to June for the first term, and the second term in September to November.

Prakerin activity in STIKS Tarakanita started in 2004 for students of academic year 2001, but the data have not been processed or analyzed to provide information for STIKS Tarakanita. The author uses of existing data as the first step of the research, which can be used as a further research material. As a preliminary research, the author uses prakerin datathat has been implemented five years back, i.e in 2015, 2014, 2013, 2012, and 2011 for students of academic year 2012, 2011, 2010, 2009, and 2008. The data which is processed only about the title of prakerin report and the name of the company where the students do prakerin activities. The classification of archive management is done to process the data title of prakerin report so that obtained information ranging from the titles of what are often taken by students up to the names of companies that often become the destination of prakerin activities, es pecially those related to archival management. Based on the data processing, there are 415 companies with 1,045 titles of prakerin report related to Secretarial, there are 203 companies that the title of prakerin reports relating to archives. Out of 203 companies, there are 127 companies whose report titles are related to Archives Management.

We want to know the satisfaction of the company in terms of problem solving of archives management that exist in the company to the activities of student's prakerin period 2011-2015. 
"Reference [2] was satisfaction is the level of feeling in which a person declares comparative results on the performance of products (services) received with the expected. High satisfaction will make loyal customers willing to buy back the goods or services, consumers want to promote the goods or services to other prospective cus tomers". "Reference[3] was cus tomer satis faction if cus tomer expectations of product quality, service quality and price are met / exceeded then achieve a high level of satisfaction".

"Reference [4] was quality can be said to exist if a service meets the exis ting specifications". "Reference [5] was Quality means superiority or excellence that exceeds the prevailing general standards". Something can be said to be qualified if there is a match between the conditions possessed by the object or service desired with the intent of the person who wants it". "Reference [6] was the quality of service is the value provided by the cus tomer to what extent the service activities are given according to customer expectations. The customer, in this case is the company, will say the services of prakerin activities are qualified if they meet their specifications. Quality of service of prakerin activity in this research is mark given abouthow good service of prakerin activity done by student of prakerin able to according to company expectation".

According to Parasuraman, Zeithml, and Berry in "Reference [7] was service quality is a meas ure to facilitate the assessment and measurement of service quality". There are 5 (five) basic elements used to measure perceptions of customers or users of services, among others a) Tangibles, namely the ability of a company in showing its exis tence to external parties. The appearance and capabilities of the company's phy sical facilities and infras tructure and the circums tances surrounding en vironment are clear evidence of the services provided by the company; b) Empathy, which is to give a sincere and personal attention given to the customer by trying to understand the customer's wishes. A company is expected to haveunderstanding and knowledge of customers, understand customer specific needs, and have a convenient operating time for customers; c) Reliability, the ability to provide promptly, accurately, and satisfactorily promised service. Performance must be in line with customer expectations that mean punctuality, equal service for all customers without errors, sympathetic attitude and high accuracy; d) Responsiveness, namely the ability to help and provide prompt and precise service to customers by conveying clear information. Allowing customers to wait in the absence of a clear reas on causes a negative perception of the quality of service; e) Assurance, the behavior of employees can foster customer confidence in the company and the company is able to create a sense of security for its customers.

According to Gerson in "Reference [3] was the relationship between service quality and customer satisfaction is determined by customer perceptions. The company's satisfaction with prakerin activities is the company's perception that its expectation has been fulfilled. The easy, fast, and precise archives management work is what the company expects".

Company satisfaction on prakerin activities will be achieved if there is a suitability between prakerin activities related to archives management given to the company with the company's expectations. Companies may experience one of the common levels of satisfaction, including a) if performance is below expectations, then the company becomes dis satis fied; b) if performance is in line with expectations, then the company becomes satisfied; c) if performance is above expectations, then the company becomes very satisfied.

According to The Liang Gie in "Reference [2] was archives are a collection of documents that are stored systematically because they have an advantage so that each time needed can be quickly rediscovered". "Reference [8] was the arrangement of archives is the arrangement of information and physical archives to facilitate redis covery. With this activity the control of the archives both physically and information can be done optimally. Currently, there are five kinds of archive arrangement sy stems: alphabetical system, problem system, number system, date system, and area system".

"Reference [2] was archives have a role as a "memory center", as a source of information, and as a "monitoring tool" that is indis pensable in every organization in the context of planning, analyzing, developing, formulating policies, decisions, reporting, accountability, appraisal, and control precisely". Archives have an important role in the process of presenting information for leaders to make decisions and formulate policies. Therefore, to be able to present accurately, timely (fast), relevant and complete information, there must be a good systemand working procedure in the field of archival management. Due to the important role of archives for life in support of the completion of work done by all personnel in the organization.

Attention needs to be given to the archives of the office in the formof a good management system, so with a good managements ystem, the system will be able to help support the efficiency of work in terms of providing information. Thus, in the activities of the organization required a handling archives system or good and correct archives management so that office archives can be maintained and easily found when needed.

Reference [9] was a problem that archive management activities that have not run properly will certainly hamper any office work associated with the provision of information quickly and accurately. The research method used is pre-survey, observation, and interview with Secretary of sub-district. The result is the management of archives related to the management, control and arrangement of archives in the Office of Tekarang sub-district less optimal due to human resources in the field of archives, as well as facilities and infrastructure archives. 
Reference [10] was raised the problem of process planning, org anizing, actuating, controlling archives in the General Adminis trative Bureau of Academic and Student Affairs (BAUAK) IAIN Walisongo Semarang. This research uses descriptivequalitative approach, because the data obtained is based on natural phenomenon or background (natural setting) as the source of direct data. The results show that the process of archiving records in BAUAK IAIN Walisongo Semarang using the principle of centralization and the principle of decentralization. The archive control process is still in the maintenance stage of the archive. The archive storage process uses alphabetical and systemof subject matter. Archive maintenance process using shelves and filing cabinets of the best materials, in other words, the implementation of filing management in BAUAK IAIN Walis ongo Semarang not too well in accordance with effective and efficient standards. The process of removal and destruction of archives needs to be done because the space and place to store archives and archive age is also limited.

Reference [11] was the problem of how to manage the archives dynamically, what obstacles faced in the implementation of archive management, and how to overcome the obstacles encountered in the implementation of archive management dynamic at the Office of Public Library and Regional Archives Semarang City? The research using this qualitative method concludes that the management of the archive is already running well, just for archive borrowing has not used the lending card archive and archive depreciation has not done archive retention schedule.

Reference [12] was focus on the problemhow the level of community satisfaction to services performed by Bitungs ari Bogor urban village officers related to adminis tration and other activities? Data analy sis techniques used were questionnaires and data processing methods using the Satisfaction Indexof the Community according to KEP / 25 / M.PAN/ 2/2004. Based on the results of data processing according to KEP / 25 / M.PAN / 2/2004 it can be seen that overall that the level of service of state apparatus in Bitungs ari sub-dis trict is at GOOD level $(78,74)$ where the certainty of service cost and environmental comfort get appreciation VERY GGOD 82,64 and $81,94)$ while the speed of service get the spotlight that mustbe more attention even though still at level GOOD $(73,61)$.

\section{Research Methods}

The type of data to be used in the research is primary data obtained from the questionnaire filling with the respondents of the company that became the prakerin student of STIKS Tarakanita period 2011-2015. Data collection techniques in this study using a questionnaire or questionnaire. The populat ion is all the company that become the prakerin student for the period of 2011-2015, which amounts to 415 companies, of which 127 companies become prakerin student of STIKS Tarakanita related archives management problems, which then will be sampled a number of 20 companies based on sampling $15.65 \%$ of 127 companies related archives management is sues [13]. The sample technique used is Proportionate Stratified Random Sampling, where this technique is used when the population has elements / members are not homogeneous and stratified proportionally [14].

In this study, the variables measured are the variable of firm satisfaction toward the variable of prakerin result by using the TERRA aspect (Tangibles, Empathy, Reliability, Responsiveness, and Assurance). Each as pect uses a Likert scale to measure attitudes, opinions, and perceptions of res pondents. With the Likert scale, the variable to be meas ured is translated into a variable indicator. Then theindicator is used as a starting point to arrange items in the form of questions or statements [14].

There are 44 items representing each aspect of TERRA (Tangibles $=14$, Empathy $=3$, Reliability $=18$, Responsiveness $=3$, and Assurance $=6$ ) which is then tested to 19 respondent companies. The results of the questionnaire then tested the validity and reliability test. Fromthe calculation of validity test, it is found that 12 items of statements that have value of $r$ count is greater than $r$ table value of 0.389 . Therefore, the 12 items of the tested statements are valid which can then be used for data retrieval. While the results of calculation reliability test obtained alpha value 0.693 . This value is greater than the value of $r$ table of 0.389 , so the instrument of this study is reliable for research.

Table 1. Results of Testing Data Processing

\begin{tabular}{rr}
\hline $\begin{array}{c}\text { Cronbach's } \\
\text { Alpha }\end{array}$ & N of Items \\
\hline .693 & 44 \\
\hline
\end{tabular}

There are 12 statement items representing each aspect of Tangibles, Empathy, Reliability, and Responsiveness. For the as pect of Assurance is not used because the 3-point statement is not reliable.

Table 2. Instrument Grille

\begin{tabular}{llll}
\hline No. & Attribute & Statement & Point \\
\hline
\end{tabular}




\begin{tabular}{llll}
\hline & & \multicolumn{1}{c}{ Number } \\
\hline 1. & Tangibles & $1.3,1.7,1.8$ & 3 \\
2. & Empathy & $2.1,2.2,2.5$, & 6 \\
& & $2.6,2.7$, & \\
& & 2.14 & \\
3. & Reliability & 3.3 & 1 \\
4. & Responsiveness & $4.2,4.4$ & 2 \\
\hline
\end{tabular}

After data collection, the collected data is processed by a) counting the number of respondents who think strongly agree, ag ree, dis agree, and strongly disagree and b) creating a Likert scale for the total of all attributes and each attribute is tangible, empathy, reliability, responsiveness, and assurance. Likert scale is made with the formula total ans wer $\mathrm{x}$ point $\mathrm{x}$ number of res pondents. The point to strongly agree is 4 , agree is 3 , dis agree is 2 , and strongly dis agree is 1 . So, Likert scale to strongly agree is the number of ans wers $\mathrm{x} 4 \mathrm{x}$ questions, to agree is the number of answers $\mathrm{x} 3 \mathrm{x}$ questions, to dis agree is the number of ans wers $\mathrm{x} 4 \mathrm{x}$ questions, to disagree is the number of answers $\mathrm{x} 2 \mathrm{x}$ questions, and to strongly disagree is the number of answers $\mathrm{x} 1 \mathrm{x}$ questions.

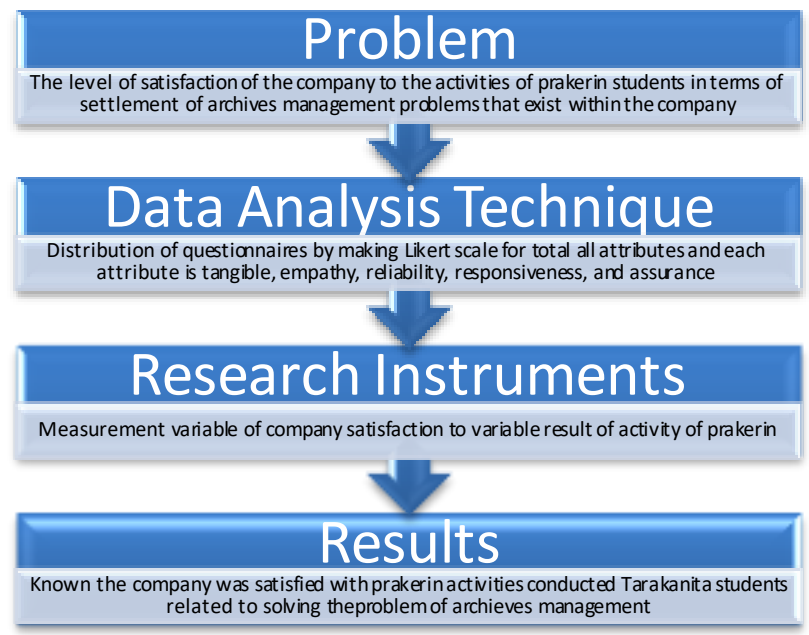

Figure 1. Thinking Framework of Research on Corporate Satisfaction Level

\section{Result and Discussion}

The population is all of the company that become the prakerin of student for the period of 2011-2015, that is 415 companies, where 127 companies become prakerin of student of STIKS Tarakanita related archives management problem, which then will be taken samples minimum 20 companies based on sampling $15,65 \%$ from 127 companies related to archives management is sues [13]. In this study, 67 questionnaires were collected. Respondents are employees appointed by the head of the company to become the Field Officer in conducting guidance and supervision of Prakerin student activities of STIKS Tarakanita. The sample technique us ed is Proportionate Stratified Random Sampling, where this technique is used when the population has elements / members are not homogeneous and stratified proportionally [14]. Respondents fill in their opinion about the satisfaction of related parties to Prakerin activities that have been done by STIKS Tarakanita students with attributes studied in the formof tangible, empathy, reliability, responsiveness, assurance. The answer av ailable is strongly agree with point 4 , agree with point 3 , disagree with point 2 , strongly disagree with point 1 .

The number of answers obtained is 804 answers (12 questions x 67 respondents). For attribute tangible obtained 201 ans wers (3questions x 67), attribute empathy obtained 402 ans wers (6 questions x 67), attribute reliability obtained 67 ans wers (1questions x 67), and responsiveness attributes obtained 134 ans wers (2 ques tion $\mathrm{x} 67)$.

\section{a. Results of Data Analysis Based on All Attributes in Corporate Satisfaction}

The basis used to measure corporate satisfaction of all attributes as a whole is the Likert Scale with the calculation: (a) Strongly agree $=67$ respondent's $x 4 \times 12$ questions $=3216$; (b) Agreed $=67$ respondent's $\times 3 \times$ 12 questions $=2412$; (c) Disagree $=67$ respondent's x 2 x 12 questions $=1608$; (d) Strongly disagree $=67$ respondent's $\mathrm{x} 1 \mathrm{x} 12$ questions $=804$.

Likert scale that can be made is: (a) Strongly agree $=2413-3216$; (b) Agree $=1609-2412$; (c) Disagree $=805$ -1608 ; (d) Strongly disagree $=0-804$. 
The result of respondent opinion obtained by summing all ans wers for all attributes, obtained the total answer point is 2179. By comparing the results of res pondents and Likert scale, then the point of 2179 identified into the agree clas sification.

\section{b. Data Analysis Result Basedon Tangible Attribute}

The basis used to measure corporate satisfaction of the tangible attribute is the Likert Scale with the calculation: (a) Strongly agree $=67$ respondent's x 4 x 3 questions $=804$; (b) Agreed $=67$ respondent's x $3 \times 3$ questions $=603$; (c) Dis agree $=67$ respondent's x 2 x 3 questions $=402$; (d) Strongly dis agree $=67$ respondent's x 1 × 3 questions $=201$.

Likert scale that can be made is: (a) Strongly agree $=604-804$; (b) Agree $=404-603$; (c) Dis agree $=202-$ 403; (d) Strongly disagree $=0-201$.

Result of student opinion obtained by summing all ans wers for tan gible attribute, obtained total ans wer value is 562. By comparing result of respondent answer and Likert scale, hence point 562 identified into agree clas sification.

\section{c. Data Analysis Result Based on Empathy Attribute}

The bas is used to meas ure the company's satis faction from the empathy attribute is the Likert Scale with the calculation: (a) Strongly agree $=67$ respondent's x 4 x 6 questions $=1608$; (b) Agreed $=67$ respondent's x $3 \times 6$ questions = 1206; (c) Disagree $=67$ respondent's $\times 2$ × 6 questions $=804$; (d) Strongly disagree $=67$ respondent's $\mathrm{x} 1 \times 6$ questions $=402$.

Likert scale that can be made is: (a) Strongly agree =1207 - 1608; (b) Agree = $805-1206$; (c) Dis agree $=403-$ 804; (d) Strongly disagree $=0-402$.

The result of the student opinion obtained by summing all answers for the empathy attribute, obtained the totalvalue of the answer is 1066. By comparing the results of respondents and Likert scale, then the point of 1066 identified into the dis agree classification.

\section{d. Data Analysis Result Based on Reliability Attribute}

The basis used to measure the company's satisfaction of the reliability attribute is the Likert Scale with the calculation: (a) Strongly agree $=67$ respondent's $x 4$ x 1 questions $=268$; (b) Agreed $=67$ respondent's $\times 3 \times 1$ questions $=201$; (c) Dis agree $=67$ respondent's x 2 x 1 questions =134; (d) Strongly dis agree =67 respondent's $\mathrm{x} 1 \mathrm{x} 1$ questions $=67$.

Likert scale that can be made is: (a) Strongly agree =202-268; (b) Agree = $135-201$; (c) Dis agree $=68-134$; (d) Strongly dis agree $=0-67$.

The result of the student opinion obtained by summing all the answers for the reliability attribute, obtained the total answer point is 164 . By comparing the results of the res pondent's answer and Likert scale, then the point of 164 identified into the agree classification.

\section{e. Data Analysis Result Bas ed on Responsiveness Attribute}

The bas is used to meas ure corporate satis faction of the responsiveness attribute is the Likert Scale with the calculation: (a) Strongly agree $=67$ respondent's x 4 x 2 question $=536$; (b) Agree $=67$ respondent's x $3 \times 2$ question $=402$; (c) Dis agree $=67$ respondent's x 2 x 2 question $=268$; (d) Strongly disagree $=67$ respondent's $x$ $1 \times 2$ question $=134$

Likert scale that can be made is: (a) Strongly agree =403-536; (b) Agree $=269-402$; (c) Dis agree $=135-268$; (d) Strongly disagree $=0-134$.

The results of student opinions obtained by summing all res ponses to attributes responsiveness, obtained the total value of answers is 387. By comparing the results of respondents and Likert scale, then the point 387 identified into the agree clas sification. 


\section{Conclusion}

From the data processing obtained some things that can be considered, among others a) Attributes in corporate satisfaction discussed in this research are tangible attributes such as facilities in the archive space, the use of Snelhecter map, and archive storage. For empathy attributes are the selection of a storage system, the skill of the archive employee, and the timer of saving or deleting the archives. For reliability attributes are speed in handling archive problem, capability of tool for handling archive problem, handling of important archives, archive storage system, and archive depreciation. To attribute responsiveness of the workings and archival equipment in accordance with developments in modern archival science; b) Based on the results of this research proves that the company is satisfied with Prakerin activities that have been done by students of STIKS Tarakanita during the Prakerin period of 2011 to 2015. Because by comparing the results of respondents and Likert scale, the point 2179 identified into the agree clas sification, it means satisfied; c) Out of 415 companies that became prakerin student period 2011-2015, it turns out 127 companies become prakerin student of STIKS Tarakanita related archives management is sues, as many as 203 companies become prakerin related archive problems, and 85 companies become prakerin related layout issues, communication, SOP (Standard Operating Company), data processing, and computer usage in work.

\section{Acknowledgement}

The author would like to thank the School of Communication and Secretary (STIKS) Tarakanita and our colleagues from Asekma Don Bosco, for their support for this work and also for anonymous reviewers, for their insightful comments that helped review the content in improving the quality of this research paper.

\section{References}

[1] Tim Penyusun, Panduan pelaksanaan dan Penulisan Laporan Prakerin. Jakarta: STIKS Tarakanita, 2016.

[2] P. Kottler, Manajemen Pemasaran, Jilid 2. Jakarta: Erlangga, 2008.

[3] M. Arief, Pemasaran Jasa Kualitas Pelayanan. Malang: Bayumedia Publisher, 2007.

[4] E. Sallis, Total Quality Management in Education. Yogyakarta: IRCiSoD, 2008.

[5] Avianti, Manajemen Kualitas Penekatan Sisi Kualitatif. Bandung: Remaja Rosdakarya, 2005.

[6] R. Lupiyoadi, Manajemen Pemasaran Jasa. Jakarta: Salemba Empat, 2006.

[7] F. Tjiptono and G. Chandra, Service, Quality Satisfaction. Yogyakarta: Andi Offset, 2005.

[8] M. Sulaiman, S. Hadiwardoyo, and Dkk, Akuisisi Nasional Arsip Orde Baru dan Kabinet Reformasi. Jakarta: Arsip Nasional Republik Indonesia, 1999.

[9] A. Kharisma, "Pengelolaan Kearsipan Pengurusan, Pengendalian dan Penataan Arsip Kantor Camat," Gov. J., vol. 1, no. 1, pp. 14-26, 2012.

[10] A. F. Mubarrok and Kardoyo, "Manajemen Kearsipan Dinamis Di Biro Administrasi Umum Akademik Dan Kemahas is waan (Bauak) IAIN W alisongo Semarang," Econ. Educ. Anal. J., vol. 4, no. 2, pp. 293 306, 2015.

[11] M.Laili, "Pengelolaan Arsip Dinamis pada Kantor Perpustakaan Umum Arsip Daerah Kota Semarang," Econ. Educ. Anal. J., vol. 3, no. 3, pp. 551-557, 2014.

[12] Pamungkas PDA, "Indeks Kepuasan Masyarakat Unit Pelayanan Kelurahan Bitungsari Bogor Menggunakan Kep/25/M.PAN/2/2004," Inf. Syst. Educ. Prof., vol. 1, no. 1, pp. 85-91, 2016.

[13] A. Fuchan, Pengantar Penelitian Dalam Pendidikan. Yogyakarta: Penerbit Pustaka Pelajar, 2012.

[14] Sugiyono, Metode Penelitian Kuantitatif, Kualitatif, dan Kombinasi (Mixed Methods). Bandung: Alfabeta, 2014. 